\title{
KAPITÁLOVÁ PRIMERANOSŤ A EFEKTÍVNOSŤ VYBRANÝCH BANKOVÝCH SEKTOROV EURÓPSKEJ ÚNIE
}

\author{
Kristína Kočišová
}

Kl’účové slová:

kapitálová primeranost', efektívnost', DEA modely, kapitálová primeranost' Tier1

Key words:

Capital adequacy, efficiency, DEA models, capital adequacy Tier1

\begin{abstract}
Abstrakt
Finančná kríza poukázala na dôležitost' sledovania a dodržiavania podmienok regulácie podnikania bánk. Jednou z oblastí regulácie je aj oblast' stanovenia výšky regulatórneho kapitálu banky, ktorá je riešená prostredníctvom koncepcie kapitálovej primeranosti. $\mathrm{Z}$ dôvodu regulácie dochádza určitým spôsobom aj k ovplyvňovaniu efektívnosti samotných bánk, a teda aj efektívnosti jednotlivých bankových sektorov. Preto ciel'om predkladaného príspevku je sledovat', či existuje vzt'ah medzi kapitálovou primeranost'ou a efektívnost'ou bankových sektorov $\mathrm{v}$ krajinách Európskej únie (EÚ) meranou pomocou vstupne orientovaných DEA modelov. Analýza bola vykonaná testovaním hypotéz. Výsledkom bolo zamietnutie nulových hypotéz, ktoré poukázalo na fakt, že žiadny z použitých ukazovatel'ov kapitálovej primeranosti nebol v roku 2009 schopný zachytit' efektívnost' bankových sektorov. Medzi efektívnost'ou a kapitálovou primeranost'ou teda existujú rozdiely, čo potvrdzuje aj výsledky korelačnej analýzy naznačujúce, že medzi analyzovanými premennými (efektívnost' verzus kapitálová primeranost') existuje iba malý a to negatívny vzt'ah.
\end{abstract}

\begin{abstract}
Financial crisis mentioned on importance of monitoring and observance of condition for regulation of banking activities. One of the regulation areas is the area of regulatory capital determination. By reason of regulation, the efficiency of banks and banking sectors are influenced too. Therefore the aim of this paper is to monitor, if there exist the relation between capital adequacy and efficiency measured by input oriented DEA models in banking sector of EU countries. The analysis was realised by testing of hypothesis. The result was the rejection of null hypothesis points to the fact, that none of used indicators of capital adequacy is able to record trend of efficiency in the banking sector in 2009. Therefore there exist differences between trend of efficiency and trend of capital adequacy that confirms also results of correlation analysis pointing to the fact, that there does exist only low and negative correlation between trends of controlled variables (efficiency vs. capital adequacy).
\end{abstract}

\section{Úvod}

Finančná kríza poukázala na dôležitost' sledovania a dodržiavania podmienok regulácie podnikania bánk. Jednou z oblastí regulácie je aj oblast' stanovenia výšky regulatórneho kapitálu banky, ktorá je riešená prostredníctvom koncepcie kapitálovej primeranosti. $\mathrm{Z}$ dôvodu regulácie dochádza určitým spôsobom aj k ovplyvňovaniu efektívnosti samotných bánk, a teda aj efektívnosti jednotlivých bankových sektorov. V modernej spoločnosti existujú mnohé metódy merania efektívnosti, ktoré vychádzajú bud’ z tradičného prístupu, 
alebo sú založené na využití informačných technológií. Metódy merania efektívnosti môžeme rozdelit' do troch základných skupín. Jedná sa o pomerové ukazovatele, parametrické metódy a neparametrické metódy. Pomerové ukazovatele patria medzi tradičné, najjednoduchšie a najčastejšie používané metódy, hlavne v oblasti finančnej analýzy. Druhú skupinu tvoria parametrické metódy, ktoré majú stochastickú povahu, čo znamená, že obsahujú aspoň jednu náhodnú zložku. Tieto metódy sa usilujú o odlíšenie neefektívnosti od efektov náhodných chýb, čo dodáva konečným výsledkom vyššiu vierohodnost'. Nevýhodou týchto metód je, že zavádzajú konkrétnu funkčnú závislost' (a odvodené predpoklady o vlastnostiach výrobných technológií), ktorá predurčuje tvar a priebeh hranice efektívnosti. Ak tieto predpoklady nezodpovedajú skutočnosti a funkčná závislost' nie je špecifikovaná správne, môže dôjst' k skresleniu konečných výsledkov. Tretia skupina metód je tvorená neparametrickými metódami merania efektívnosti. Neparametrické metódy majú deterministickú povahu, čo znamená, že neobsahujú náhodnú zložku. Preto nie je možné účinne eliminovat' negatívne dopady náhodných chýb, chýb v meraní alebo nedokonalých dát na meranie efektívnosti. Pri neparametrických metódach nie sú predpoklady na výrobnú technológiu určené tak striktne ako pri parametrických metódach, preto je u analyzovaných produkčných jednotiek prípustná vyššia miera vol'nosti. Farrellov (1957) pôvodný článok o meraní efektívnosti viedol k rozvoju mnohých prístupov na meranie vstupnej a výstupnej efektívnosti a k rozvoju prístupov analýzy produktivity. Medzi týmito prístupmi, stochastický prístup Stochastic Frontier Approach (SFA) vytvorený Aignerom, Lovellom a Schmidtom (1977); a Data Envelopment Analysis (DEA) vytvorená Charnesom, Cooperom a Rhodesom (1978) majú najväčší priekopnícky význam.

\section{Kapitálová primeranost' a efektívnost'}

Všetky hlavné bankové aktivity sú regulované pravidlami. Ciel'om regulácie finančných rizík je zabránit' prípadnému pádu finančnej inštitúcie, a tým ochránit’ finančné zdroje klientov uložené v bankách, zabezpečit' dôveru verejnosti vo finančný systém, zdravý chod bankového systému a podporit' menovú stabilitu. Regulácia a bankový dohl'ad predstavujú v podstate aktívnu reprezentáciu klientov, nakol'ko klienti nemajú dostatok informácií na správne ohodnotenie rizikovosti komerčných bánk. Ked’že medzi jednotlivými krajinami existujú rozdiely je potrebné, aby dochádzalo k postupnému zbližovaniu až zjednocovaniu pravidiel regulujúcich ich činnost'. Medzi postupne zjednocujúce sa pravidlá možno zaradit' pravidlá stanovujúce primeranost' kapitálu banky, primeranost' likvidity, pravidlá angažovanosti, povinnost' bánk poskytovat' regulačným inštitúciám a bankovému dohl'adu požadované informácie, pravidlá ochrany pred nelegálnymi praktikami a oblast' povinných minimálnych rezerv. Zjednotenie regulačných pravidiel by malo vytvorit' rovnaké podmienky pre podnikanie všetkých bánk a tak znížit' riziko nestability a nesprávneho fungovania celého finančného sektora.

V rámci regulácie je špeciálna pozornost' venovaná vlastnému kapitálu banky, pretože je považovaný za najvhodnejší zdroj ochrany banky pred nesolventnost'ou. Problematikou stanovenia výšky kapitálu sa zaoberá koncepcie kapitálovej primeranosti. Podstatou tejto koncepcie je zmerat' riziká daného subjektu a na základe toho stanovit' odpovedajúcu minimálnu úroveň vlastného kapitálu. Hodnota vlastného kapitálu má byt' dostatočne vel'ká, aby pokryla budúce potenciálne straty z dnešných rizík. Základnou myšlienkou teda je, že akákol'vek potenciálna strata finančnej inštitúcie v budúcnosti, ktorá je spojená s dnešnými rizikami, by mala byt' krytá vlastnými zdrojmi finančnej inštitúcie, t.j. kapitálom akcionárov a nie prostriedkami vkladatel'ov. (Kočišová a Vokorokosová, 2009) 
Oblast'ou regulácie kapitálovej primeranosti sa zaoberá hlavne Bazilejský výbor pre bankový dohl'ad, ktorý pravidelne aktualizuje regulačné opatrenia $v$ tejto oblasti. Na základe pôvodnej koncepcie vypracovanej týmto výborom bol stanovený základný ukazovatel kapitálovej primeranosti ako pomer regulatórneho kapitálu k rizikovo váženým aktívam. S rozvojom finančných trhov a ekonomík však bolo potrebné tento ukazovatel' postupne modifikovat', pričom požiadavka kapitálovej primeranosti ostávala nezmenená na úrovni $8 \%$. V súčasnosti sa ukazovatel' kapitálovej primeranosti stanovuje tak, aby vel'kost' regulatórneho kapitálu banky pokryla požiadavku na krytie úverového, trhového i operačného rizika. Okrem základného ukazovatel'a kapitálovej primeranosti sa môžeme stretnút' aj s ukazovatel'om kapitálovej primeranosti Tier1. Jedná sa o čiastkový ukazovatel', ktorý sa vypočítava iba z jednej z troch základných zložiek regulatórneho kapitálu ${ }^{1}$. Ukazovatel' Tier1 je jedným z finančným ukazovatel'ov používaných na meranie finančného zdravia bánk, ktorý meria pomer základného vlastného kapitálu banky (Tier1) k rizikovo váženým aktívam ${ }^{2}$. Ako reakcia na finančnú krízu bol v súčasnosti Bazilejským výborom vypracovaný súbor nových štandardov, ktoré sa označujú ako Basel III. Tieto štandardy boli schválené na stretnutí krajín G20 v Soule. Ich implementácia sa má začat’ v januári 2013 a plne implementované by mali byt' do januára 2019. Basel III prináša zmeny vo všetkých troch pilieroch predošlých štandardov, pričom základom sú zmeny týkajúce sa prvého piliera s ciel’om znížit' pravdepodobnost' zlyhania bánk. Basel III nemení spôsob výpočtu kapitálovej požiadavky, ale prináša zmenu v kvalite kapitálu, nové ukazovatele likvidity a pákového pomeru, a stanovuje potrebu vytvárania kapitálových vankúšov.

Samotná regulácia činnosti bánk ovplyvňuje aj hospodárenie týchto subjektov. Napríklad požiadavka na držané likvidné aktíva má vplyv na celkový objem prostriedkov, ktoré banka môže poskytnút' vo forme úverov, pretože prostriedky použité na splnenie ukazovatel'ov likvidity nie je možné použit' na úverovanie. Ked’že tieto likvidné aktíva väčšinou prinášajú nižší výnos ako úvery, prejaví sa regulácia aj vo výške zisku. Požiadavka na rastúcu minimálnu úroveň základného vlastného kapitálu predstavuje riziko zníženia aktívnych obchodov v dôsledku nedostatku kapitálu. Rovnako v súvislosti s vytváranými vankúšmi sa dá očakávat' rast nákladov v bankovom sektore. Všetky tieto regulačné opatrenia sa určitým spôsobom premieta aj do efektívnosti samotných bánk, a teda aj do efektívnosti jednotlivých bankových sektorov. Efektívnost' bankových sektorov ovplyvňuje v neposlednom rade aj konkurenčnú schopnost' ekonomiky. Č́m efektívnejšie funguje bankový sektor, tým je menšia pravdepodobnost' jeho zlyhania, a teda aj vyššia pravdepodobnost' dlhodobého potenciálneho rastu ekonomiky. Následne stabilná ekonomika s vyššou úrovňou ekonomického rastu prináša širšiu oblast' konkurenčných výhod. Preto je dôležité zameriavat' sa na meranie a sledovanie efektívnosti a hl'adanie príčin neefektívnosti.

V odbornej literatúre sa niekedy môžeme stretnút' so skutočnost'ou, že sa pojem efektívnost' zamieňa s pojmami produktivita a ziskovost'. V skutočnosti však medzi týmito pojmami existujú podstatné rozdiely. Ide o rozdiely z hl'adiska metodologickej koncepcie, ale aj rozdiely $\mathrm{v}$ spôsobe merania. Ziskovost' vychádza $\mathrm{z}$ výšky zisku k vytvoreniu ktorého prispievajú použité výrobné faktory, s dôrazom na prácu a jej vybavenost' znalost'ami a schopnost'ou využívat' informačné technológie. Na druhej strane produktivita a efektívnost'

\footnotetext{
1 Základnými komponentmi regulatórneho kapitálu sú: Tier1 (základný vlastný (jadrový) kapitál), Tier2 (dodatkové vlastné zdroje) a Tier3 (doplnkové vlastné zdroje; krátkodobý podriadený dlh).

${ }^{2}$ Požadovaná hodnota ukazovatel'a Tier1 je stanovená na úrovni $6 \%$. V prípade hodnoty ukazovatel'a vyššej ako $6 \%$ je banka považovaná za dobre kapitalizovanú. Ak sa hodnota pohybuje v rozpätí od $4 \%$ do $6 \%$, hovoríme o adekvátne kapitalizovanej banke, hodnota v rozpätí od $3 \%$ do $4 \%$ hovorí o podkapitalizovanej banke a hodnota menšia ako $3 \%$ označuje významne podkapitalizovanú banku.
} 
skúmajú hlavne vzt'ah medzi použitými vstupmi a vyprodukovanými výstupmi. Pri skúmaní efektívnosti je ciel'om identifikovat' najviac (najmenej) efektívnu jednotku vo vzt'ahu k výkonnosti ostatných analyzovaných jednotiek. Pri výpočte efektívnosti sa za celok považuje súbor skúmaných jednotiek. Aby analýza poskytovala relevantné výsledky, je nutné skúmat' produkčné jednotky s podobnými vlastnost'ami a charakteristikami, ktoré je možné aproximovat' spoločným súborom vstupov a výstupov (Stavárek, 2005a).

\section{DEA modely merania efektívnosti}

DEA je úlohou lineárneho programovania, ktorá predpokladá, že neexistujú náhodné chyby. Používa sa na meranie technickej efektívnosti. Je jednou z neparametrických metód merania relatívnej efektívnosti produkčných jednotiek (DMU, Decision Making Unit). Na efektívne fungovanie týchto jednotiek majú vplyv všetky použivané vstupy aj produkované výstupy. V posledných rokoch sa táto metóda stáva stále viac populárnou pri meraní efektívnosti v národných bankových sektoroch (Pastor et al., 1997; Berger a Mester, 1997; Darrat et al., 2002; Jemric a Vujcic, 2002), ale aj pri komparácii bankových subjektov na globálnom bankovom trhu (Casu a Molyneux, 2003; Stavárek, 2005a, 2005b). Na Slovensku, v Rakúsku a Česku sa problematikou DEA zaoberajú hlavne Luptáčik a Bohm (2010), Sudzina (2001), Jablonský a Dlouhý (2004), Jablonský a Grmanová (2009), Stavárek (2005a; 2005b), Kuljovská a Stavárek (2008), a Vincová (2005; 2006). V DEA modeloch posudzujeme $n$ DMU, pričom každá DMU spotrebuje $m$ rôznych vstupov na vyprodukovanie $s$ rôznych výstupov. V literatúre sa môžeme stretnút's dvoma základnými DEA modelmi, CCR a BCC modelom. CCR model vytvorený Charnesom, Cooperom, Rhodesom predpokladá, že DMU pracuje za podmienok konštantných výnosov z rozsahu. Pre praktické riešenie je využívaný najmä duálny tvar CCR modelu s doplnkovými premennými. Doplnkové premenné môžeme ekonomicky interpretovat' ako rezervy, teda nadbytočné vstupy, resp. stratenú výrobu. Stanovenie technickej efektívnosti týmto spôsobom patrí medzi dvojfázové úlohy lineárneho programovania. Duálny tvar vstupne orientovaného CCR modelu s doplnkovými premennými používaný na meranie celkovej technickej efektívnosti môžeme zapísat' v tvare:

$$
\begin{array}{ll}
\text { Minimalizovat' } & \theta_{q}-\varepsilon\left[\sum_{i=1}^{\mathrm{m}} \mathrm{s}_{\mathrm{i}}^{-}+\sum_{r=1}^{s} s_{r}^{+}\right] \\
\text {Za podmienok } & \sum_{j=1}^{n} x_{i j} \lambda_{j}+s_{i}^{-}=\theta_{q} X_{i q} \\
& \sum_{j=1}^{n} y_{r j} \lambda_{j}-s_{r}^{+}=Y_{r q} \\
& \lambda_{j} ; s_{r}^{+} ; s_{i}^{-} \geq 0
\end{array}
$$

kde

$\theta_{q}-$ miera technickej efektívnosti $\mathrm{DMU}_{\mathrm{q}}-$ vstupne orientovaný model,

$\lambda_{j}$ - váha priradená $j$-tej produkčnej jednotke DMU,

$y_{r j}$ - empirická hodnota výstupu $r$ pre $j$-tú DMU,

$x_{i j}$ - empirická hodnota vstupu $i$ pre $j$-tú DMU,

$s_{r}^{+}-$doplnková hodnota $r$-tého výstupu,

$s_{i}^{-}$- doplnková hodnota $i$-tého vstupu,

$\varepsilon-$ konštanta non-Archimedean, vo výške $10^{-8}$. 
Model (1) predpokladá konštantné výnosy z rozsahu. Predpoklad konštantných výnosov z rozsahu môžeme akceptovat' len v tom prípade, ak všetky DMU vykonávajú činnost' pri optimálnej vel'kosti. Nedokonalá konkurencia, finančné obmedzenia, regulačné opatrenia a d'alšie faktory však spôsobujú, že DMU nefungujú pri svojej optimálnej vel'kosti. Preto bol za účelom prekonania tohto problému vyvinutý DEA model umožňujúci kalkulovat' $\mathrm{s}$ variabilnými výnosmi z rozsahu. Tento model sa označuje ako BCC model (Banker et al., 1984). Vstupne orientovaný BCC model môže byt' zapísaný v tvare:

$$
\begin{array}{ll}
\text { Minimalizovat } & \theta_{q}-\varepsilon\left[\sum_{i=1}^{\mathrm{m}} \mathrm{s}_{\mathrm{i}}^{-}+\sum_{r=1}^{s} s_{r}^{+}\right] \\
\text {Za podmienok } & \sum_{j=1}^{n} x_{i j} \lambda_{j}+s_{i}^{-}=\theta_{q} X_{i q} \\
& \sum_{j=1}^{n} y_{r j} \lambda_{j}-s_{r}^{+}=Y_{r q} \\
& \lambda_{j} ; s_{r}^{+} ; s_{i}^{-} \geq 0 \\
& \sum_{j=1}^{n} \lambda_{j}=1
\end{array}
$$

Hodnoty efektívnosti vypočítané na základe BCC modelu sa nazývajú aj čistou technickou efektívnost'ou, pretože BCC model eliminuje čast' neefektívnosti, ktorá je spôsobená neadekvátnou vel'kost'ou produkčnej jednotky. Rozdel'uje teda efektívnost' nameranú CCR modelom na čistú technickú efektívnost' a efektívnost' z rozsahu (Kočišová, 2012).

\section{Metodológia výskumu}

Ciel'om predkladaného príspevku je sledovat', či v analyzovanom roku existuje vzt'ah medzi kapitálovou primeranost'ou a efektívnost'ou bankových sektorov vybraných krajín EÚ. Overením hypotéz sa pokúsime dokázat' či existuje vzt’ah medzi sledovanými premennými, a ak áno, či je tento vzt’ah pozitívny alebo negatívny. V publikáciách zaoberajúcimi sa touto problematikou sa totižto stretávame s rôznymi názormi na vzt'ah medzi efektívnost'ou a kapitálovou primeranost'ou. Na jednej strane štúdiu poukazujú na pozitívny ${ }^{3}$ vzt'ah medzi sledovanými premennými, na strane druhej je tento vzt'ah charakterizovaný ako negatívne korelovaný. Vo všeobecnosti bola naformulovaná nasledovná hypotéza, ktorá bola predmetom d’alšieho testovania. Hypotéza: Neexistuje štatisticky významný rozdiel medzi efektívnost'ou a kapitálovou primeranost'ou. Zamietnutie hypotézy môžeme interpretovat', tak, že v roku 2009 žiadny z použitých ukazovatel'ov kapitálovej primeranosti nie je schopný zachytit' efektívnost' bankových sektorov meranú vstupne orientovanými DEA modelmi. Nemôžeme jednoznačne povedat', že v roku najviac efektívny bankový sektor bude mat' zároveň aj najnižšiu hodnotu ukazovatel'ov kapitálovej primeranosti. Predmetom analýzy bol stav sledovaných parametrov v 26. bankových sektoroch krajín EÚ v roku 2009.

\footnotetext{
${ }^{3}$ Menšia miera efektívnosti je spojená s menšou hodnotou ukazovatel’a celkovej kapitálovej primeranosti, ked’že menej efektívnejšie banky vykonávajú na vykrytie strát rizikovejšie aktivity, teda rastie aj hodnota rizikovo vážených aktív a požiadaviek na krytie ostatných rizík pri danom objeme vlastného kapitálu.

4 Väčšia miera efektívnosti je spojená s menšou hodnotou ukazovatel'a kapitálovej primeranosti. Napr. efektívnejšia banka pravdepodobne využíva aj sofistikovanejšie prístupy k riadeniu rizík, preto jej regulátor môže poskytnút' určité zvýhodnenia, čo banke umožní znížit' hodnotu kapitálu a tieto prostriedky využit' na tvorbu zisku. Nižšia hodnota vlastného kapitálu pri danej úrovni rizikovo vážených aktív a požiadaviek na krytie ostatných rizík potom povedie k pokles hodnoty ukazovatel'ov kapitálovej primeranosti.
} 
Aby bolo možné vykonat' analýzu medzi efektívnost'ou meranej DEA modelmi a kapitálovou primeranost'ou, bolo najprv potrebné určit', aké údaje budú v DEA modeloch hodnotené ako vstupy a výstupy ${ }^{5}$. Rozhodovanie o tom, ktoré charakteristiky DMU použijeme v analýze ako vstupy a výstupy a aké množstvo vstupov a výstupov zahrnút' do analýzy nie je jednoduchou úlohou. Preto na základe praktických skúseností boli sformulované nasledovné predpoklady použitia DEA modelu (Klieštik, 2009):

1. Celkový počet vstupov a výstupov $(m+s)$ sa snažíme minimalizovat' v záujme zvýšenia vypovedacej schopnosti odhadovaného modelu, pretože s rastúcim počtom vstupných a výstupných charakteristík rastie aj počet obmedzujúcich podmienok potrebných na vyjadrenie hranice efektívnosti. Odporúča sa preto, aby celkový počet vstupov a výstupov neprekročil $1 / 3$ množstva skúmaných DMU, t.j. $(m+s)<n / 3$.

2. Vysoko korelované vstupy (resp. výstupy) sú zbytočné. Všetky, až na jeden z nich, môžu byt' vynechané bez zhoršenia výsledkov modelu. Túto úpravu však treba robit' opatrne. Vylúčenie príliš vel'kého počtu vstupov môže spôsobit', že efektívna DMU sa môže stat' neefektívnou.

3. Vstup, ktorý neovplyvňuje žiadny výstup, signalizuje, že množina výstupov je neúplná. Tento vstup reprezentuje použité zdroje, ktoré produkujú nemeratel’né výstupy. Ked’že takéto výstupy nemôžu byt' merané, tento vstup sa z d'alšej analýzy vynecháva.

4. Dostupnost' dát nesmie ovplyvnit' výber vstupov a výstupov.

5. Ak nie je jednoznačné, či daný materiálny tok je vstupom alebo výstupom, tak tok, ktorý svojou redukciou vylepší efektívnost' DMU, sa považuje za vstup. Ak je potrebné na zvýšenie efektívnosti DMU daný tok rozšírit', tak sa tento tok považuje za výstup.

6. Uvažované vstupy a výstupy musia obsahovat' všetky s analýzou súvisiace aktivity všetkých DMU.

Predtým ako začneme vykonávat' analýzu efektívnosti bankových sektorov EÚ musíme najprv preskúmat', či nami zvolené vstupy a výstupy vyhovujú predpokladom použitia DEA modelov. Pre potreby analýzy boli ako vstupy a výstupy zvolené nasledujúce premenné: Vstupné premenné: Počet bánk (úverových inštitúcií) (PB), Celkové aktíva v tis. EUR (CA), Hmotný a nehmotný majetok ako percento z CA (HaNM), Vklady iné ako od úverových inštitúcií v tis. EUR (V), Mzdové náklady v tis. EUR (MN), Mzdové náklady pripadajúce na jednu banku v tis. EUR (MN/PB). Výstupné premenné: Úrokové príjmy v tis. EUR (ÚP), Čisté príjmy z poplatkov a provízií v tis. EUR (PP), Celkové úvery v tis. EUR (Ú1), Celkové úvery ako percento z CA (Ú2).

Celkovo bolo pre potrebu analýzy zvolených 10 premenných. Zvolený výber však nespĺn̆a odporúčania prvého predpokladu, aby celkový počet vstupov a výstupov neprekročil 1/3 množstva skúmaných DMU. Ked’že počet analyzovaných krajín EÚ je 26, budeme z uvažovanej skupiny vstupov a výstupov vyrad'ovat' najmenej relevantné tak, aby sme získali skupinu premenných vytvorenú z troch vstupov a troch výstupov.

\footnotetext{
${ }^{5}$ Pre potrebu našej analýzy bola banka vnímaná ako inštitúcia, ktorá prijíma rôzne typy depozít od rôzneho typu vkladatel'ov, aby potom s prispením práce a fixného kapitálu tieto peňažné prostriedky premenila na úvery poskytnuté rozličným ekonomickým subjektom. Bol teda uplatnený sprostredkovatel'ský prístup k definovaniu súboru vstupov a výstupov bankovej činnosti.
} 
Pri skúmaní splnenia druhej a tretej podmienky sme vykonali korelačnú analýzu medzi hodnotami jednotlivých vstupov a výstupov bankových sektorov. Miera korelácie je dôležitým ukazovatel'om, ktorý má vel'ký vplyv na robustnost' DEA modelu. Korelačná analýza je nevyhnutnou podmienkou stanovenia vhodných vstupov a výstupov. Na jednej strane, ak je nájdená vel'mi vysoká korelácia medzi jednou vstupnou premennou a inou vstupnou premenou (resp. medzi jednotlivými výstupnými premennými), táto vstupná (resp. výstupná) premenná môže byt' považovaná za ekvivalent inej. Preto tento vstup (resp. výstup) môže byt' z modelu vynechaný. Na druhej strane, ak vstup má vel'mi nízku koreláciu s iným vstupom (alebo korelácia medzi výstupmi je vel'mi nízka), môže to naznačovat', že táto premenná nie je vhodná pre daný model. Korelačná analýza bola urobená pre každú kombináciu premenných. Výsledky korelačnej analýzy zobrazuje Tabul'ka 1.

Tabul'ka 1. Hodnoty korelačných koeficientov medzi jednotlivými vstupmi a výstupmi

\begin{tabular}{|l|c|c|c|c|c|c|c|c|c|c|}
\hline & PB & CA & HaNM & V & MN & MN/PB & ÚP & PP & \multicolumn{1}{|c|}{} & Ú2 \\
\hline PB & 1,0000 & 0,4979 & $-0,0517$ & 0,4375 & 0,2283 & $-0,1279$ & 0,4073 & 0,3292 & 0,4424 & $-0,3310$ \\
\hline CA & & 1,0000 & $-0,0244$ & 0,9877 & 0,9253 & 0,4414 & 0,9096 & 0,9551 & 0,9920 & $-0,4898$ \\
\hline HaNM & & & 1,0000 & 0,0514 & 0,1798 & 0,1325 & 0,0352 & 0,1402 & 0,0299 & 0,3420 \\
\hline V & & & & 1,0000 & 0,9530 & 0,4611 & 0,9352 & 0,9676 & 0,9962 & $-0,4437$ \\
\hline MN & & & & & 1,0000 & 0,6301 & 0,8821 & 0,9897 & 0,9469 & $-0,3888$ \\
\hline MN/PB & & & & & & 1,0000 & 0,5130 & 0,6041 & 0,4260 & $-0,3253$ \\
\hline ÚP & & & & & & & 1,0000 & 0,8803 & 0,9195 & $-0,4804$ \\
\hline PP & & & & & & & & 1,0000 & 0,9628 & $-0,4224$ \\
\hline Ú1 & & & & & & & & & 1,0000 & $-0,4451$ \\
\hline Ú2 & & & & & & & & & & 1,0000 \\
\hline
\end{tabular}

Zdroj: výpočty autora

Na základe výsledných hodnôt jednotlivých korelačných koeficientov bol z analýzy ako prvý vynechaný vstup, ktorý mal najnižšiu priemernú koreláciu s celou skupinou uvažovaných výstupov (Tabul'ka 2). Týmto vstupom bol HaNM, kde priemerný korelačný koeficient daného vstupu s celou uvažovanou skupinou výstupov dosiahol hodnotu 0,1368.

Tabul'ka 2. Priemerná korelácia vstupov

\begin{tabular}{|l|c|c|c|c|c|r|}
\hline & PB & CA & HaNM & V & MN & MN/PB \\
\hline Priemerná korelácia vstupu s výstupmi & 0,2120 & 0,5917 & 0,1368 & 0,6138 & 0,6074 & 0,3044 \\
\hline Priemerná korelácia vstupu s ostatnými vstupmi & 0,3307 & 0,6380 & 0,2146 & 0,6485 & 0,6528 & 0,4229 \\
\hline
\end{tabular}

Zdroj: výpočty autora

Ako druhý bol z analýzy vyradený výstup, ktorý mal najnižšiu priemernú koreláciu s celou skupinou uvažovaných vstupov (Tabul'ka 3). Týmto výstupom bola hodnota celkových úverov vyjadrená ako percento z celkových aktív (Ú2), kde priemerný korelačný koeficient daného výstupu s celou uvažovanou skupinou vstupov dosiahol hodnotu -0,2728. 
Tabul'ka 3. Priemerná korelácia výstupov so skupinou uvažovaných vstupov

\begin{tabular}{|c|c|c|c|c|}
\hline & ÚP & PP & Ú1 & Ú2 \\
\hline Priemerná korelácia výstupu so vstupmi & 0,6137 & 0,6643 & 0,6389 & $-0,2728$ \\
\hline
\end{tabular}

Zdroj: výpočty autora

Tret'ou vyradenou premennou bol vstup, ktorý mal najnižšiu priemernú koreláciu s celou skupinou uvažovaných vstupov (Tabul'ka 2). Išlo o premennú počet bánk (PB), kde korelačný koeficient dosiahol hodnotu 0,3307. Po preštudovaní odbornej literatúry ${ }^{6}$ sme sa ako poslednú premennú rozhodli z analýzy vylúčit' mzdové náklady $(\mathrm{MN})$. V modeli boli ponechané mzdové náklady pripadajúce na jednu banku, ked’že v sebe integrujú dve z pôvodne uvažovaných vstupných premenných. Podl'a štvrtej podmienky dostupnost' dát nesmie ovplyvnit' výber vstupov a výstupov. Pre potreby analýzy boli údaje čerpané z databázy ECB (Statistical Data Warehouse). Ked’že dáta boli dostupné v pomerne širokom rozsahu, boli vybrané viaceré vstupné a výstupné premenné, $\mathrm{z}$ ktorých sa vyššie uvedeným spôsobom stanovila konečná množina vstupov a výstupov v rozsahu 6. Zarad'ovanie jednotlivých skúmaných premenných medzi vstupy a výstupy bankových sektorov (podmienky 5 a 6 ) sme vykonali po preštudovaní literatúry zameranej na skúmanie efektívnosti bankových sektorov, preto predpokladáme, že nami zahrnuté vstupy a výstupy obsahujú všetky aktivity skúmaných bankových sektorov, ktoré súvisia s analýzou efektívnosti. Analýzou podmienok použitia DEA modelov bola stanovená skupina šiestich analyzovaných vstupných a výstupných premenných. Vstupné premenné: Celkové aktíva v tis. EUR (CA), Vklady iné ako od úverových inštitúcií v tis. EUR (V), Mzdové náklady pripadajúce na jednu banku v tis. EUR (MN/PB). Výstupné premenné: Úrokové príjmy v tis. EUR (ÚP), Čisté príjmy z poplatkov a provízií v tis. EUR (PP), Celkové úvery v tis. EUR (Ú1).

\section{Prezentácia výsledkov výskumu}

Predmetom analýzy bolo hodnotenie vzt'ahu medzi kapitálovou primeranost'ou a efektívnost'ou v 26. bankových sektorov krajín EÚ v roku 2009. Kapitálová primeranost' bola meraná prostredníctvom ukazovatel'a celkovej kapitálovej primeranosti (CKP) a ukazovatel'a kapitálovej primeranosti Tier1 (KP Tier1). Efektívnost' bankových sektorov bola meraná prostredníctvom vstupne orientovaných DEA modelov. Pri meraní efektívnosti sme rôznymi kombináciami vytvorili 9 modelov, ktoré boli použité na meranie vstupnej CCR a BCC efektívnosti. Výsledky nameranej efektívnosti prostredníctvom jednotlivých modelov zobrazujú Tabul'ky 4a a 4b.

\footnotetext{
${ }^{6}$ Pastor et al., 1997; Berger a Mester, 1997; Darrat et al., 2002; Jemric a Vujcic, 2002
} 
Tabul'ka 4a. Popisná štatistika, vstupne orientovaný CCR model

\begin{tabular}{|c|c|c|r|r|r|r|c|}
\hline \multirow{2}{*}{ Model $^{\mathbf{7}}$} & \multicolumn{2}{|c|}{ Počet } & Priemerná & $\begin{array}{c}\text { Standardná } \\
\text { odchýlka }\end{array}$ & $\begin{array}{c}\text { Maximálna } \\
\text { efektívnost' }\end{array}$ & $\begin{array}{c}\text { Minimálna } \\
\text { efektívnost' }\end{array}$ & $\begin{array}{c}\text { Počet efektívnych } \\
\text { bankových sektorov }\end{array}$ \\
\hline $\mathbf{1}$ & 3 & 3 & 0,9520 & 0,0695 & 1,0000 & 0,7311 & 14 \\
\hline $\mathbf{2}$ & 3 & 2 & 0,9347 & 0,0839 & 1,0000 & 0,7074 & 12 \\
\hline $\mathbf{3}$ & 3 & 1 & 0,6436 & 0,2211 & 1,0000 & 0,2017 & 3 \\
\hline $\mathbf{4}$ & 2 & 2 & 0,8989 & 0,0912 & 1,0000 & 0,6868 & 7 \\
\hline $\mathbf{5}$ & 2 & 1 & 0,5821 & 0,2023 & 1,0000 & 0,1827 & 1 \\
\hline $\mathbf{6}$ & 1 & 2 & 0,7886 & 0,1444 & 1,0000 & 0,5536 & 3 \\
\hline $\mathbf{7}$ & 1 & 1 & 0,5610 & 0,1909 & 1,0000 & 0,1827 & 1 \\
\hline $\mathbf{8}$ & 2 & 3 & 0,9167 & 0,0830 & 1,0000 & 0,6868 & 8 \\
\hline $\mathbf{9}$ & 1 & 3 & 0,8144 & 0,1393 & 1,0000 & 0,5560 & \\
\hline
\end{tabular}

Zdroj: výpočty autora

Tabul'ka 4b. Popisná štatistika, vstupne orientovaný BCC model

\begin{tabular}{|c|c|c|c|c|c|c|c|}
\hline \multirow[b]{2}{*}{ Model } & \multicolumn{2}{|c|}{ Počet } & \multirow{2}{*}{$\begin{array}{l}\text { Priemerná } \\
\text { efektívnost' }\end{array}$} & \multirow{2}{*}{\begin{tabular}{|c|}
$\begin{array}{c}\text { Štandardná } \\
\text { odchýlka }\end{array}$ \\
\end{tabular}} & \multirow{2}{*}{$\begin{array}{l}\text { Maximálna } \\
\text { efektívnost' }\end{array}$} & \multirow{2}{*}{$\begin{array}{l}\text { Minimálna } \\
\text { efektívnost' }\end{array}$} & \multirow{2}{*}{$\begin{array}{c}\text { Počet efektívnych } \\
\text { bankových sektorov }\end{array}$} \\
\hline & Vstupov & Výstupov & & & & & \\
\hline 1 & 3 & 3 & 0,9737 & 0,0589 & 1,0000 & 0,7785 & 20 \\
\hline 2 & 3 & 2 & 0,9629 & 0,0680 & 1,0000 & 0,7785 & 16 \\
\hline 3 & 3 & 1 & 0,7892 & 0,2494 & 1,0000 & 0,2069 & 12 \\
\hline 4 & 2 & 2 & 0,9467 & 0,0791 & 1,0000 & 0,6932 & 12 \\
\hline 5 & 2 & 1 & 0,7166 & 0,2423 & 1,0000 & 0,1911 & 7 \\
\hline 6 & 1 & 2 & 0,8510 & 0,1528 & 1,0000 & 0,5702 & 7 \\
\hline 7 & 1 & 1 & 0,6906 & 0,2402 & 1,0000 & 0,1911 & 5 \\
\hline 8 & 2 & 3 & 0,9634 & 0,0707 & 1,0000 & 0,6932 & 16 \\
\hline 9 & 1 & 3 & 0,8844 & 0,1449 & 1,0000 & 0,5882 & 9 \\
\hline
\end{tabular}

Zdroj: výpočty autora

Na základe popisných štatistík jednotlivých modelov môžeme vidiet', že priemerná miera efektívnosti nameraná pri BCC modeloch (Tabul'ka 4b) bola vyššia ako pri CCR modeloch (Tabul'ka 4a). Zároveň môžeme pozorovat' skutočnost', že s rastúcim počtom vstupných a výstupných premenných dochádza $\mathrm{k}$ rastu priemernej efektívnosti, ale aj $\mathrm{k}$ rastu počtu efektívnych bankových sektorov. $\mathrm{Na}$ druhej strane, pokles vstupných a výstupných premenných vedie k poklesu priemernej efektívnosti aj počtu efektívnych bankových sektorov. Túto skutočnost' popisuje aj teória $\mathrm{v}$ podmienkach použitia DEA modelov ktorá naznačuje, že vynechanie príliš vel'kého počtu vstupov resp. výstupov z analýzy môže viest' k tomu, že efektívna DMU sa môže stat' neefektívnou.

Pozorovaním výsledkov získaných CCR a BCC modelmi (Tabul'ka 5) môžeme konštatovat', že obidva prístupy vykazujú pomerne vysoké hodnoty dosahovanej priemernej efektívnosti v sledovanom období avšak získané výsledky efektívnosti sú v súlade $\mathrm{s}$ inými štúdiami

\footnotetext{
${ }^{7}$ Model 1 = 3 vstupy (CA, V, MN/PB) a 3 výstupy (ÚP, PP, Ú1); Model $2=3$ vstupy (CA, V, MN/PB) a 2 výstupy (PP, Ú1); Model $3=3$ vstupy (CA, V, MN/PB) a 1 výstup (PP); Model $4=2$ vstupy (CA, V) a 2 výstupy (PP, Ú1); Model $5=2$ vstupy (CA, V) a 1 výstup (PP); Model $6=1$ vstup (V) a 2 výstupy (PP, Ú1); Model $7=1$ vstup (V) a 1 výstup (PP); Model $8=2$ vstupy (CA, V) a 3 výstupy (ÚP, PP, Ú1); Model $9=1$ vstup (V) a 3 výstupy (ÚP, PP, Ú1).
} 
zaoberajúcimi sa analýzou efektívnosti bankového sektora prostredníctvom DEA modelov ${ }^{8}$ (Vincová, 2006).

Tabul'ka 5. Charakteristika efektívnosti a kapitálovej primeranosti

\begin{tabular}{|l|r|r|r|r|}
\hline Krajina & $\mathbf{C C R}^{\mathbf{9}}(\%)$ & $\mathbf{B C C}^{\mathbf{1 0}}(\%)$ & $\mathbf{C K P}(\%)$ & KP Tier1 $(\%)$ \\
\hline Rakúsko & 83,7712 & 88,7710 & 12,7227 & 9,2653 \\
\hline Belgicko & 67,7320 & 71,4989 & 17,2738 & 13,2336 \\
\hline Bulharsko & 87,2252 & 94,9255 & 11,3601 & 9,3525 \\
\hline Cyprus & 63,0931 & 66,5390 & 12,1372 & 9,5427 \\
\hline Česká republika & 71,8252 & 73,3912 & 13,9721 & 12,2923 \\
\hline Nemecko & 77,5411 & 90,0932 & 14,3024 & 10,6779 \\
\hline Dánsko & 82,6377 & 83,8085 & 16,0973 & 13,4764 \\
\hline Estónsko & 81,8251 & 93,5937 & 12,6055 & 9,4212 \\
\hline Španielsko & 74,6330 & 88,5936 & 12,2325 & 9,3383 \\
\hline Fínsko & 62,9598 & 65,1132 & 14,6091 & 13,7935 \\
\hline Francúzsko & 87,4128 & 100,0000 & 12,2389 & 10,1198 \\
\hline Vel'ká Británia & 80,0711 & 100,0000 & 14,9458 & 9,9342 \\
\hline Grécko & 66,3860 & 70,2536 & 11,749 & 10,7635 \\
\hline Mad'arsko & 84,2781 & 86,4929 & 14,3711 & 11,9099 \\
\hline Írsko & 68,3967 & 73,2120 & 12,7863 & 9,794 \\
\hline Taliansko & 95,7167 & 100,0000 & 11,6504 & 8,2929 \\
\hline Litva & 85,5282 & 100,0000 & 12,9 & 9,3 \\
\hline Luxembursko & 84,6208 & 87,4686 & 18,1216 & 15,5865 \\
\hline Lotyšsko & 84,0704 & 98,1075 & 13,7161 & 10,7948 \\
\hline Malta & 64,5078 & 90,0886 & 24,1987 & 21,3851 \\
\hline Holandsko & 66,2524 & 78,0648 & 14,9574 & 12,4769 \\
\hline Pol'sko & 95,2459 & 98,6299 & 13,4606 & 12,1019 \\
\hline Portugalsko & 85,5873 & 88,4136 & 10,4804 & 7,8289 \\
\hline Rumunsko & 100,0000 & 100,0000 & 15,771 & 12,9164 \\
\hline Slovinsko & 79,9636 & 86,8673 & 11,6791 & 9,0261 \\
\hline Slovenská republika & 67,5274 & 73,2245 & 12,7458 & 11,615 \\
\hline Zdroj: Statstica & & & \\
\hline
\end{tabular}

Zdroj: Statistical Data Warehouse a výpočty autora

$\mathrm{Na}$ základe vypočítaných hodnôt korelačných koeficientov medzi charakteristikami uvedenými v Tabul'ke 5 sme zistili existenciu vysokej pozitívnej korelácie medzi hodnotami priemernej CCR a BCC efektívnosti $(0,8358)$ a medzi hodnotami ukazovatel'ov kapitálovej primeranosti $(0,9413)$. Naopak korelačná analýza poukázala na strednú negatívnu koreláciu medzi CCR efektívnost'ou a ukazovatel'mi kapitálovej primeranosti; a malú až triviálnu negatívnu koreláciu medzi BCC efektívnost’ou a ukazovatel'mi kapitálovej primeranosti. Tieto nízke hodnoty korelačných koeficientov naznačujú, že medzi analyzovanými premennými existuje iba malý a to negatívny vzt’ah.

\footnotetext{
${ }^{8}$ Napr. Pastor et al. (1997) vo svojej práci dospeli k záveru, že priemerná CCR efektívnost' sa vo Francúzsku pohybovala okolo 95\%, v Španielsku 82,2\%, v Belgicku 80,6\%, v Taliansku 77,3\%, v Nemecku $6 \%$, v Rakúsku $60,8 \%$ a vo Vel'kej Británii dosahovala 53,7\%. Na druhej strane Berger a Mester (1997) vo svojej štúdii popisujú priemernú efektívnost' v sledovanom období nasledovne: Dánsko 85\%, Fínsko 86\%, Švédsko 85\%, Grécko 91\%, Taliansko 98\%, Španielsko 87\%, Vel'ká Británia 90\% a Francúzsko 95\%.

${ }^{9}$ Priemerná hodnota efektívnosti meranej deviatimi CCR modelmi v danej krajine.

${ }^{10}$ Priemerná hodnota efektívnosti meranej deviatimi BCC modelmi v danej krajine.
} 
Predpoklad malého negatívneho vzt'ahu medzi analyzovanými premennými bol overovaný aj testovaním hypotéz o vzt'ahu medzi efektívnost'ou a kapitálovou primeranostou. Samotné testovanie hypotéz bolo realizované prostredníctvom párového t-testu, ktorý patrí medzi parametrické testy používané pre závislé premenné. Pre každú odpovedajúcu dvojicu hodnôt vieme vypočítat' rozdiel, tzv. diferenciu. Tým vznikne súbor hodnôt diferencií rovnakého rozsahu, aký mali obidva pôvodné znaky. Diferencie pre každú dvojicu hodnôt znaku udávajú, o kol'ko je hodnota v prvom znaku vyššia ako v druhom (Hudec a kol., 2007).

Testujeme hypotézy o zhode stredných hodnôt dvoch závislých premenných súborov, čo matematicky môžeme zapísat' v tvare $\mathrm{H}_{0}: \mu_{1}=\mu_{2}$. Nulovú hypotézu zamietame $\mathrm{v}$ prípade, že je p-hodnota pre obojstranný interval nižšia ako 0,05. Zamietnutím nulovej hypotézy prijímame alternatívnu hypotézu, že existuje štatisticky významný rozdiel v stredných hodnotách zvolených súborov. V prípade našej analýzy môžeme dáta pre jednotlivé krajiny považovat' za spárované, preto bol pri testovaní použitý práve párový t-test. Tabul'ka 6 zobrazuje stredné hodnoty premenných použitých $\mathrm{v}$ jednotlivých testoch, hodnotu tštatistiky, p-hodnotu na zvolenej hladine pravdepodobnosti a rozhodnutie o prijatí, resp. zamietnutí hypotézy. Tabul'ka zobrazuje výsledky 4 testov, v ktorých boli testované hypotézy o vzt'ahu medzi efektívnost'ou a kapitálovou primeranost'ou v roku 2009. Predmetom testovania bolo nasledovných 4 hypotéz ${ }^{11}$ :

$\mathrm{HO}_{1 ; 2}$ : Neexistuje štatisticky významný rozdiel medzi efektívnost'ou meranou CCR resp. BCC modelom $^{12}$ a celkovou kapitálovou primeranost'ou.

$\mathrm{HO}_{3 ; 4}$ : Neexistuje štatisticky významný rozdiel medzi efektívnost'ou meranou CCR resp. BCC modelom $^{12}$ a kapitálovou primeranost'ou meranou ukazovatel'om Tier1.

Tabul'ka 6. Výsledky párového t-testu naformulovaných hypotéz

\begin{tabular}{|c|c|c|c|c|}
\hline Hypotéza & Názov premennej & $\begin{array}{l}\text { Stredná } \\
\text { hodnota }\end{array}$ & $\begin{array}{c}\text { Hodnota t štatistiky } \\
\text { (p-hodnota) }\end{array}$ & Rozhodovacie pravidlo \\
\hline \multirow{2}{*}{1} & celková kapitálová primeranost' & 13,96480385 & \multirow{2}{*}{$\begin{array}{l}-28,50379375 \\
(2,6139 \mathrm{E}-19)^{*} \\
\end{array}$} & \multirow{2}{*}{ H0 zamietame } \\
\hline & CCR miera efektívnosti & 78,80032906 & & \\
\hline \multirow{2}{*}{2} & celková kapitálová primeranost' & 13,96480385 & \multirow{2}{*}{$\begin{array}{c}-31,08874826 \\
(1,67607 \mathrm{E}-21)^{*}\end{array}$} & \multirow{2}{*}{ H0 zamietame } \\
\hline & BCC miera efektívnosti & 86,42889188 & & \\
\hline \multirow{2}{*}{3} & ukazovatel' Tier1 & 11,31690769 & \multirow{2}{*}{$\begin{array}{c}-29,20793699 \\
(7,66229 \mathrm{E}-21)^{*}\end{array}$} & \multirow{2}{*}{ H0 zamietame } \\
\hline & CCR miera efektívnosti & 78,80032906 & & \\
\hline \multirow{2}{*}{4} & ukazovatel' Tier1 & 11,31690769 & \multirow{2}{*}{$\begin{array}{c}-31,19107290 \\
(1,54696 \mathrm{E}-21)^{*}\end{array}$} & \multirow{2}{*}{ H0 zamietame } \\
\hline & BCC miera efektívnosti & 86,42889188 & & \\
\hline
\end{tabular}

$* \alpha=0,05$ Zdroj: výpočty autora

Zamietnutie nulových hypotéz poukazuje na fakt, že žiadny z použitých ukazovatel'ov kapitálovej primeranosti nie je schopný zachytit' efektívnost' bankových sektorov. Nemôžeme jednoznačne povedat', že bankový sektor, ktorý bol najviac efektívny bude mat' zároveň aj najnižšiu hodnotu ukazovatel'ov kapitálovej primeranosti. Rozdielne hodnoty testovacích

\footnotetext{
11 Predmetom testovania boli aj čiastkové hypotézy, v ktorých bol testovaný vzt’ah medzi efektívnost'ou meranou jednotlivými CCR a BCC modelmi (osobitne každý z deviatich CCR a každý z deviatich BCC modelov) a kapitálovou primeranost'ou (CKP, aj KP Tier1) v krajinách EÚ v roku 2009. Výsledkom vo všetkých 36. prípadoch testovania bolo zistenie zamietnutia nulovej hypotézy, rovnako ako je tomu aj $\mathrm{v}$ prípade priemernej miery efektívnosti. Z tohto dôvodu Tabul'ka 6 zobrazuje iba výsledky testov pre priemerné hodnoty meranej efektívnosti $v$ jednotlivých krajinách.

${ }^{12}$ Priemerná hodnota efektívnosti meranej deviatimi CCR resp. BCC modelmi v danej krajine.
} 
štatistík dokonca poukazujú na odlišnú úroveň rozdielnosti medzi testovanými premennými. Vyššie absolútne hodnoty testovacích štatistík poukazujú na väčšie rozdiely medzi analyzovanými premennými, čo potvrdzujú aj nižšie p-hodnoty poukazujúce na zamietnutie jednotlivých hypotéz. Vyššia hodnota testovaných štatistík medzi BCC efektívnost'ou a ukazovatel'mi kapitálovej primeranosti potvrdila väčšie rozdiely medzi testovanými premennými ako je tomu v prípade CCR modelu, čo zároveň potvrdilo aj výsledky korelačnej analýzy. Ako môžeme vidiet' v Tabul'ke 6 vo všetkých prípadoch sa potvrdilo zamietnutie nulových hypotéz. Nemôžeme teda tvrdit', že neexistuje štatistiky významný rozdiel medzi efektívnost'ou a kapitálovou primeranost'ou v jednotlivých krajinách. Medzi mierou efektívnosti a kapitálovej primeranosti teda existujú rozdiely, čo potvrdzuje aj výsledky korelačnej analýzy naznačujúce, že medzi analyzovanými premennými (efektívnost' verzus kapitálová primeranost') existuje iba malý a to negatívny vzt'ah.

\section{Záver}

V čase finančnej krízy si mnohí uvedomili rizikovost' bankových aktivít a s tým aj dôležitost' sledovania a dodržiavania podmienok regulácie podnikania bánk. Jednou z oblastí regulácie podnikania bánk je aj oblast' stanovenia výšky regulatórneho kapitálu banky upravená koncepciou kapitálovej primeranosti. Požiadavka na určitú minimálnu úroveň kapitálu vo vzt’ahu k rizikovosti vykonávaných aktivít sa určitým spôsobom premieta aj do efektívnosti samotných bánk, a teda aj do efektívnosti jednotlivých bankových sektorov. Napríklad požiadavka na držané likvidné aktíva má vplyv na celkový objem prostriedkov, ktoré banka môže poskytnút' vo forme úverov, pretože prostriedky použité na splnenie ukazovatel'ov likvidity nie je možné použit' na úverovanie. Ked’že tieto likvidné aktíva väčšinou prinášajú nižší výnos ako úvery, prejaví sa regulácia aj vo výške zisku. Ciel'om predkladaného príspevku bolo sledovat', či existuje vzt'ah medzi kapitálovou primeranost'ou a efektívnost'ou bankových sektorov krajín EÚ v roku 2009 meranou pomocou vstupne orientovaných DEA modelov. Analýza bola vykonaná testovaním hypotéz. Výsledkom bolo zamietnutie nulových hypotéz, ktoré poukázalo na fakt, že žiadny z použitých ukazovatel'ov kapitálovej primeranosti nebol v roku 2009 schopný zachytit' efektívnost' bankových sektorov. Nemôžeme teda jednoznačne povedat', že bankový sektor, ktorý bol najviac efektívny bude mat' zároveň aj najnižšiu hodnotu ukazovatel'ov kapitálovej primeranosti. Aj ked' táto problematika nie je v odbornej literatúre predmetom častého skúmania, s podobnými zisteniami sa môžeme stretnút' napr. v práci autorov Wirnkara a Tankoa (2008).

\section{Literatúra:}

[1] AIGNER, D. J. - LOVELL, C. A. K. - SCHMIDT, P. (1977): Formulation and Estimation of Stochastic Frontier Production Function Models. Journal of Econometrics, 6, č. 1, s. 21 - 37, ISSN: 0304-4076.

[2] BANKER, R.D. - CHARNES, A. - COOPER, W.W. (1984): Some Models for Estimating Technical and Scale Inefficiencies in Data Envelopment Analysis. Management Science, 30, č. 9, 1078-1092, ISSN: 0025-1909.

[3] BERGER, A. - MESTER, L. (1997): Inside the black box: What explains differences in the efficiencies of financial institutions? Journal of banking and finance, č. 21, s. 895 974, ISSN: 0378-4266. 
[4] CASU, B. - MOLYNEUX, P. (2003): A Comparative Study of Efficiency in European Banking. Applied Economics, 35, č. 17, s. 1865 - 1876., ISSN: 0003-6846.

[5] CHARNES, A. - COOPER, W. - RHODES, E. (1978): Measuring the Efficiency of Decision-making Units. European Journal of Operational Research, 2, č. 6, 429 - 444, ISSN: 0377-2217.

[6] DARRAT, A. F. - TOPUZ, C. - YOUSEF, T. (2002): Assessing Cost and Technical Efficiency of Banks in Kuwait. Ruston, LA: Lousiana Tech University.

[7] FARRELL, M. J. (1957): The Measurement of Productive Efficiency. Journal of the Royal Statistical Society, Series A, 120, č. 3, s. 253 - 290, ISSN: 0035-9238.

[8] HUDEC, O. - SISÁKOVÁ, J. - TARTALOVÁ, A. - ŽELINSKÝ, T. (2007): Štatistické metódy v ekonomických vedách. Košice: Elfa. ISBN: 978-80-8086-059-2.

[9] JABLONSKÝ, J. - DLOUHÝ, M. (2004): Modely hodnocení efektivnosti produkčních jednotek, Praha: Professional Publishing. ISBN: 80-86419-49-5.

[10] JABLONSKÝ, J. - GRMANOVÁ, E. (2009): Analýza efektívnosti slovenských a českých poist’ovni pomocou modelov analýzy obalu dát. Ekonomický časopis, 57, č. 9, s. 857-869, ISSN: 0013-3035.

[11] JEMRIC, I. - VUJCIC, B. (2002): Efficiency of banks in Croatia: A DEA Approach, Zagreb: Croatian National Bank, ISBN: 1331-8586.

[12] KLIEŠTIK, T. (2009): Kvantifikácia efektivity činností dopravných podnikov pomocou Data Envelopment Analysis. In: E+M Ekonomie a management, 1, s. 133-145, ISSN: 1212-3609.

[13] KULJOVSKÁ, J. - STAVÁREK, D. (2008): Analýza efektívnosti slovenských bánk parametrickou metódou DEA. Ekonomická revue, 11, č. 2, s. 65 - 79, ISSN: 1212-3951.

[14] KOČIŠOVÁ, K. (2012): Aplikácia DEA modelov pri analýze technickej efektívnosti pobočiek komerčnej banky. Ekonomický časopis, 60, č. 2, s. 169 - 186, ISSN: 00133035.

[15] KOČIŠOVÁ, K. - VOKOROKOSOVÁ, R. (2009): Manažment bankových operácií. Košice: Elfa, ISBN: 978-80-8086-118-6.

[16] LUPTACIK, M. - BOHM, B. (2010): Efficiency Analysis of a Multisectoral Economic System. Central European journal of operational research, 18, č. 4, s. $609-619$, ISSN: 1613-9178.

[17] PASTOR, J. M. - PÉREZ, F. - QUESADA, J. (1997): Efficiency Analysis in Banking Firms: An International Comparison. European Journal of Operational Research, 98, č. 2, s. 359 - 407, ISSN: 0377-2217.

[18] STAVÁREK, D. (2005a): Zprostředkovatelská činnost bank ve střední Evropě. Část 1. - Mezinárodní analýza efektivnosti. Ekonomie a Management, 8, č. 1, s. 33 - 53, ISSN: 1212-3609.

[19] STAVÁREK, D. (2005b): Zprostředkovatelská činnost bank ve střední Evropě. Část 2. - Analýza determinanti̊ efektivnosti. Ekonomie a Management, 8, č. 2, s. 59 - 71, ISSN: 1212-3609.

[20] SUDZINA, F. (2001): Analýza obalu údajov. Ekonomický časopis, 49, č. 5, s. 970 984, ISSN: 0013-3035.

[21] VINCOVÁ, K. (2005): Využitie DEA modelov na hodnotenie efektívnosti. BIATEC, 13, č. 8, s. $24-28$, ISSN: 1335-0900.

[22] VINCOVÁ, K. (2006): Meranie efektívnosti vbankovom sektore. Komparácia slovenského a českého bankového sektora. Acta Academica Karviniensia, 8, č. 1, s. 249 - 260, ISSN: 1212-415X.

[23] WIRNKAR, A.D. - TANKO, M. (2008): CAMEL(S) and bank performance evaluation: the way forward. Nigeria, Available at: <http://ssrn.com/abstract=1150968>. 
JEL G21

Ing. Kristína Kočišová, PhD.

Odborná asistentka Katedra bankovníctva a investovania

Ekonomická fakulta

Technická univerzita

Nemcovej 32, 04001 Košice, Slovenská republika

Tel.: +42155602 2157

kristina.kocisova@tuke.sk 